\title{
The Impact of Knowledge Management on SMEs Performance in the city of Bandung
}

\author{
Ardi Apriliadi, Adman
}

\begin{abstract}
Micro, small and medium enterprises (SMEs) have a large role in economic activities. SMEs are the largest provider of employment, an important player in the development of local, national and international economic activities and community empowerment. Lacking of knowledge about the latest production technology and how to run quality control on products, meaning that here knowledge has an important role for the performance of SMEs. Therefore, the core of the research study is focused on one of the factors that influence the performance of SMEs, namely knowledge management. Based on this, the main problem revealed in this study is how the impact of knowledge management on the performance of SMEs. This research was conducted on SMEs in the city of Bandung. This study consisted of two variables, namely Knowledge Management $(X)$ and SMEs Performance (Y). Knowledge management in this study consisted of four processes (Knowledge creation, knowledge storage, knowledge transfer/sharing and knowledge utilization) while SMEs Performance used a balanced scorecard approach (financial perspective, internal perspective of business processes, customer and stakeholder perspectives, and learning and growth perspective).The method used in this study is a survey method in the form of an explanatory survey. Data collection techniques by means of questionnaires with Likert scale models, which were analyzed using simple regression. And the respondents in this study were SMEs in Bandung, which numbered 99 UKM. Based on the results of the study, it can be seen that knowledge management has a positive and significant influence on the performance of SMEs in the city of Bandung. Where Knowledge Management Capabilities (Knowledge creation, acquisition, knowledge storage, knowledge transfer / sharing, knowledge utilization) are proven to have a positive and significant influence on the performance of SMEs (financial perspective, internal perspective of business processes, customer and stakeholder perspectives, and learning and growth perspective).
\end{abstract}

Index Terms: Knowledge Management, Knowledge Management Capabilities, SMEs Performance.

\section{INTRODUCTION}

Micro, small and medium enterprises (SMEs) have a large role in the nation's economic activities. In Law No. 20 of 2008 states that SMEs aim to grow and develop their businesses in order to build a national economy based on equitable economic democracy. According to (Iqbal, Agha, Ali, \& Qureshi, 2016), The SME sector consists of small businesses and medium-sized companies that contribute to an important part of the world economy, in developed countries and developing

Revised Manuscript Received on October 15, 2019

Ardi Apriliadi, Indonesia Endowment Fund for Education (LPDP), Full Time Students, Master of Management ScienceProgram, Universitas Padjadjaran.ardi.apriliadi@gmail.com

Adman, Lecturer atFaculty of Economicsand Business Education, Universitas Pendidikan Indonesia. adman@upi.edu.

countries, the size of the small and medium economy as the best role is important. Small and medium enterprises (SMEs) form the potential economic backbone of many regions and make a greater contribution to jobs than large companies(Chin, Hamid, Rasli, \& Tat, 2014). Especially if it is associated with its role during the crisis, it serves as a buffer against the resilience of the economy of the community and even functions as social security, because it is through this existence that many hopes are imposed especially on economic activities, especially as a source of community income in 2015 Micro, Small and Medium Enterprises(Sarwono, 2015)has an important role in the economy in Indonesia. MSMEs have a proportion of $99.99 \%$ of the total business actors in Indonesia, contributing around $60 \%$ of GDP. The GDP is an accumulation of various economic sectors of MSMEs, including: 1) Agriculture, Livestock, Forestry and Fisheries (48.85\%); 2) Trade, Hotels and Restaurants (28.83\%); 3) Transportation and Communication (6.88\%); 4) Processing Industry (6.41\%); 5) Services (4.52\%); 6) Finance, Leasing and Company Services (2.37\%); 7) Buildings (1.57\%); 8) Mining and Excavation (0.53\%); and 9) Electricity, Gas and Clean Water $(0.03 \%)$.

Some of the important roles of SMEs in the Indonesian economy are its position as a major player in economic activities in various sectors, namely: the largest provider of employment; important players in developing local economic activities and community empowerment; new market creators and sources of innovation; and its contribution in maintaining the balance of payments through export activities.According to (Chin, Hamid, Rasli, \& Baharun, 2012)in today's increasingly globalized economy, small and medium enterprises (SMEs) are now regarded as the main sources of dynamism, innovation and flexibility in developing and developing countries, as well as the economies of industrialized countries, they contribute greatly to economic development and job creation. Nevertheless, there are still some internal and external obstacles that must be faced by SME actors. One of the obstacles for SMEs.

(Sarwono, 2015)namely Human Resources (HR): Lack of knowledge about the latest production technology and how to run quality control on products, meaning that here knowledge has an important role for the performance of SMEs. As stated by (Kimaiyo, Kapkiyai, \& Sang, 2015)mentioned that all knowledge management processes are very important to improve company performance. So these obstacles and constraints do not discourage SMEs from developing their business.

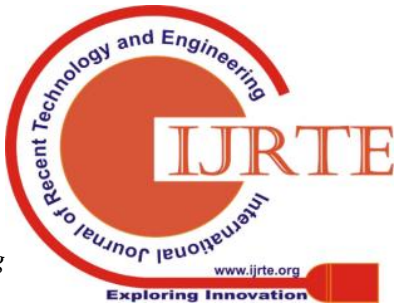




\section{The Impact of Knowledge Management on SMEs Performance in the city of Bandung}

Opportunities to increase business capacity of SMEs still have considerable prospects, especially for SME economic sectors that contribute large portions of GDP.

The city of Bandung has potential industrial, both are large, medium, small and micro industries. From the data of the Office of Cooperatives, SMEs, and Trade Industry, in 2015 in the City of Bandung there were 10 Large Industries, and 825 medium industrial units. In the small and micro industry group, the food and beverage industry is the industry with the largest number of business units. The number of Business Units and Manpower for Small and Micro Industries in Bandung City in 2015 is as follows:

TABLE 1 : TOTALSMESIN BANDUNG CITY YEAR 2014-2016

No Industrial Type

1 Food and Beverage Industry

2 Textile and Garment Industry Leather Industry, Leather Goods, and Footwear

Wood Industry, Wood and Cork

4 Products and Woven Goods from $42 \quad 42$ Bamboo, Rattan

5 Chemical, Pharmaceutical and Traditional Medicine Industries

Rubber Industry, Goods from

Rubber and Plastics

Manufacture of Metal Goods,

7 Computers, Electronic, Optical and Electrical Equipment

8 Machinery and Equipment

8 Industry

9 Furniture Industry

10 Other Processing Industry

Source: (Bandung City Central Statistics Agency, 2017)

From the data above we can see that the number of SMEs in Bandung City from 2014 to 2016 did not experience an increase, whereas if we look at the existence of SMEs it is very important for the economy and community empowerment.

Human resources are one of the crucial problems faced by SMEs, therefore one effort is needed, namely by applying knowledge management as an effort to improve the quality of human resources which will ultimately improve the performance of SMEs. Basically, in today's competitive business environment, organizational performance cannot be ignored in formulating a company's strategy.(Wang, Bhanugopan, \& Lockhart, 2015)discusses that performance is at the core of all activities in the organization because determining organizational survival as organizational performance is a reflection of the way organizations exploit real and intangible resources to achieve their goals.

Performance according to (Armstrong \& Taylor, 2014)is the result of three determinants: 1) Knowledge of facts and facts (called declarative knowledge); 2) Knowledge of how everything is done and the skills to do it (called procedural knowledge and skills), and 3) Motivation to act, to spend effort and to survive (called motivation).For this reason, knowledge plays an important role in organizational performance.Besides, according to(Anggadwita \& Mustafid, 2014), several factors affect the SMEs performance, namely entrepreneurship, human resource competence, innovation, and sustainability. The result is expected to contribute to SMEs to maintain and improve their performance.

The above opinion illustrates that knowledge which is part of human resource competence plays an important role in achieving company performance. "The success of a company is more directed at its ability related to knowledge and learning than its physical assets."(M. H. R. Torabi, Kyani, \& Falakinia, 2016). Therefore, people will hope that for companies to be successful, they must exploit methodically their knowledge assets (Bolisani \& Bratianu, 2017).Meanwhile, (M. H. R. Torabi et al., 2016)believe that knowledge management is managing knowledge through an organizational and systematic process to organize, stabilize, implement, and share explicit and implicit knowledge from employees, improve organizational performance, and create value.Investigation on the relationship between knowledge management capabilities and organizational performance is very important because findings can help businesses to further explore the consequences of knowledge management(Liu \& Deng, 2015). In this study the performance measures used use a balance scorecard, where companies not only measure financial elements, but involve consumers, business processes and learning.According to (Kaplan \& Norton, 1996)measures of company performance are seen from four perspectives, namely finance, customers, internal business processes, and learning and growth.According to (Cho \& Korte, 2014), there is a lack of studies that investigate the relationship between knowledge management capabilities and non-financial performance. So we will focus on linking knowledge management to the performance of SMEs in financial and non-financial measures using the balanced scorecard approach.

\section{LiteratURE REVIEW}

\section{A. Knowledge Management}

Knowledge management is the process of using meticulous steps to acquire, design, manage and share knowledge within an organization to achieve better performance such as reduced costly rework, faster work and use of best practices(Abubakar, Elrehail, Alatailat, \& Elçi, 2017).KM is a set of procedures, infrastructures, and technical and managerial tools designed for creation, sharing, and implementation of information and knowledge inside and outside organizations. (M. H. R. Torabi et al., 2016).In addition, knowledge management is a systematic or structured activity to improve organizational capabilities (if in an organizational context, because bias also occurs in the context of groups and individuals) through the process of managing knowledge both tacit and explicit, including relating to acquisition, transfer, storage, retrieving knowledge to support knowledge creation as a basis for generating innovation, thus supporting optimal achievement of organizational performance(Budihardjo, 2017). 
Knowledge management is a systematic set of procedures for acquiring, designing, managing, sharing and implementing knowledge both tacit and explicit to support the achievement of optimal organizational performance.KM is a system to create, collect,organize, distribute, and use knowledge in organization or individual, purposed to increase learning process and organization performance. Managerial Competence is knowledge and capability those related with managerial capability needed to handle organization's tasks(Adman; Suwatno; Tjutju Yuniarsih, 2017)

Knowledge as one of the competencies of human resources has an important role in improving the SMEs performance. This is in line with the opinion(M. H. R. Torabi et al., 2016)which states that the success of a company is more directed at its ability related to knowledge and learning than its physical assets. Knowledge management is managing knowledge through an organizational and systematic process to organize, stabilize, implement, and share explicit and implicit knowledge from employees, improve organizational performance, and create value.

We can conclude that, knowledge has very important in the company, it is possible to achieve optimal goals by using information. (a) research result (Gharakhani \& Mousakhani, 2012)shows that the three factors of knowledge management capability (knowledge acquisition, knowledge sharing, and knowledge application) have a positive and significant influence on the performance of SMEs organizations (sales growth, quality improvement, and customer satisfaction); (b) research result (Ha, Lo, \& Wang, 2016)mentions that the ability of knowledge management processes is conceptualized as four dimensions of construction: knowledge acquisition, knowledge conversion, knowledge application, and knowledge protection while organizational performance is divided into two dimensions, non-financial performance and financial performance. This paper anticipates that the four capabilities of knowledge management processes are important antecedents of organizational performance, which in turn have a positive relationship with non-financial performance and financial performance of SMEs; (c) Research results(Kimaiyo et al., 2015). Knowledge management skills (knowledge acquisition, knowledge conversion, knowledge application, and knowledge protection) have a positive and significant influence on company performance; and (d) research result (Mills \& Smith, 2011). The results show that some sources of knowledge (eg organizational structure, application of knowledge) are directly related to organizational performance, while others (eg technology, knowledge conversion), although preconditions are important for knowledge management, are not directly related to organizational performance.

\section{B. Knowledge Management Capabilities}

Knowledge management capabilities (KMC) is one of the organizational capabilities that focuses on the knowledge management area(Cho \& Korte, 2014). Knowledge management capabilities (KMC) contribute to organizational performance in the form of innovation, new product development, and competitiveness. This is due to the fact that achieving superior organizational performance depends on tangible assets such as natural resources and intangible assets such as knowledge (Alaarj, Abidin-Mohamed, \& Binti Ahmad Bustamam, Salwa, 2016). In this research, KMC focuses on four processes, knowledge creation / acquisition, knowledge storage, knowledge transfer / sharing, and knowledge utilization.

\section{1) Knowledge creation/acquisition}

Knowledge Creation or Knowledge Acquisition: This process involves applying new knowledge or replacing current content in the organization's explicit and tacit knowledge, this requires organizations to seek new knowledge and information, both inside and outside the organization(Si Xue, 2017). Knowledge creation is a process in which new knowledge is created through four sub-processes (socialization, combination, externalization, and internationalization) of the theory of continuous organizational knowledge creation (Shujahat, Ali, Nawaz, Durst, \& Kianto, 2018). Knowledge creation involves activities related to the entry of knowledge into the system, namely development, discovery, and capture and understanding. Some examples of tools for the creation of collective knowledge are meetings, discussions, and group work. (M. H. R. Torabi et al., 2016). "Creating knowledge requires the presence of someone or a group of people who come up with new ideas, new concepts, innovative products or processes, etc."(Pandey, 2014). This is the company's ability to build new ideas and solutions related to various dimensions of organizational activities, from managerial procedures to products / services to technological innovations(Tubigi, Alshawi, \& Alalwany, 2013). According to research result (Alaarj et al., 2016)knowledge acquisition has a positive and significant effect on organizational performance. These results are in line with research(Kimaiyo et al., 2015)knowledge acquisition has a positive and significant effect on organizational performance. According to (Tubigi et al., 2013)knowledge creation and acquisition as the most influential process in organizational performance.

2) Knowledge storage

$\mathrm{KS}$ can be defined as an activity that includes separating knowledge into various categories, transferring knowledge, and storing knowledge in organizational databases(Mahdi, Nassar, \& Almsafir, 2018). This raises the concept of organizational memory, which means the existence of knowledge in various structures and formats (i.e. electronic databases, written documentation, individual and team tacit knowledge, and recognizable knowledge. Organizational memory consists of personal memory (action, experience, and observation individuals) as well as information archives (inside and outside the organization), sharing knowledge and interactions, ecology (physical work arrangements) and organizational culture, transformation, structure (formal organizational roles)(Abubakar et al., 2017). Scholars have explicitly stated that the key factor in achieving this is organizational memory related to the organization's ability to store and maintain knowledge.(M. H. R. Torabi et al., 2016). 


\section{The Impact of Knowledge Management on SMEs Performance in the city of Bandung}

\section{3) Knowledge transfer/sharing}

The third stage is the transfer / sharing of knowledge carried out from the individual and group sectors to other sectors, this is so that the knowledge that has been obtained and stored can be transferred to other parties, meaning that here involves the sender and recipient of information. As mentioned by(M. H. R. Torabi et al., 2016)knowledge transfer / sharing consists of communication between two parties, the sender and the recipient. The role of the sender and receiver can be played by all teams or individuals. The process of sharing knowledge is seen as a socio-cultural interaction that involves the exchange of experiences, ideas, and skills through departments and organizations(Alaarj et al., 2016). Knowledge sharing activities through knowledge (i.e. skills, expertise or information based on experience, as well as reports, manuals and documents relating to user needs, possible innovations, barriers and other areas) are exchanged through informal dialogues, face-to-face meetings, and group discussions(Islam, Agarwal, \& Ikeda, 2017). The aim of sharing knowledge can be to create new knowledge by combining existing knowledge differently or becoming better at exploiting existing knowledge(Gharakhani \& Mousakhani, 2012), meaning that how here individuals, groups and organizations can interact and communicate with each other to exchange knowledge that they have acquired so as to produce new knowledge, (Kimaiyo et al., 2015)argues that the failure of employees to share knowledge is a small value for the organization.

4) Knowledge utilization

Knowledge utilization is defined as a routine that applies and exploits newly modified knowledge to modify and create operating routines that improve performance results (Lee, Hung, \& Chau, 2011). Therefore, through the utilization of knowledge gained knowledge can be transformed from potential capabilities into realized and dynamic capabilities that impact organizational performance(Mills \& Smith, 2011), through the utilization of knowledge acquired knowledge can be transformed from potential capabilities into realized and dynamic capabilities that impact organizational performance (Kimaiyo et al., 2015). The research result from (Alaarj et al., 2016)prove that knowledge utilization has a positive and significant effect on organizational performance.

TABLE2:KNOWLEDGE MANAGEMENT CAPABILITIES

\begin{tabular}{|c|c|}
\hline Authors & Process \\
\hline (M. H. R. & Knowledge creation, Knowledge Storage \\
\hline $\begin{array}{l}\text { Torabi et al., } \\
\text { 2016) }\end{array}$ & $\begin{array}{l}\text { and Retrieval, Knowledge Distribution } \\
\text { andTransfer, Knowledge Application }\end{array}$ \\
\hline $\begin{array}{l}\text { (Ha et al., } \\
\text { 2016) }\end{array}$ & $\begin{array}{l}\text { Knowledge acquisition, knowledge } \\
\text { conversion, knowledge application, and } \\
\text { knowledge protection }\end{array}$ \\
\hline (Alaarj et al., & Knowledge Acquisition, Knowledge \\
\hline 2016) & Sharing, Knowledge Utilization \\
\hline $\begin{array}{l}\text { (Islam et al., } \\
\text { 2017) }\end{array}$ & $\begin{array}{l}\text { Knowledge capture/creation, knowledge } \\
\text { sharing/ transfer, application/use of } \\
\text { knowledge }\end{array}$ \\
\hline (F. Torabi \& & Knowledge culture, Tacit and explicit \\
\hline El-Den, 2017) & knowledge, Knowledge sharing \\
\hline $\begin{array}{l}\text { (Gharakhani \& } \\
\text { Mousakhani, } \\
\text { 2012) }\end{array}$ & $\begin{array}{l}\text { Knowledge acquisition, knowledge sharing, } \\
\text { and knowledge application }\end{array}$ \\
\hline (Mahdi et al., & Knowledge identification, Knowledge goals \\
\hline
\end{tabular}

formulating, Knowledge generating, Knowledge storage, Knowledge sharing, Knowledge application.

Knowledge creation, Knowledge capture,

(Abubakar et Knowledge organization, Knowledge al., 2017) storage, Knowledge dissemination, Knowledge application.

KnowledgeInfrastructurecapability :

(Cho \& Korte, Technology, Structure, Culture, Incentive;

2014) Knowledge processcapability : Acquisition, Conversion, Application, Protection.

(Daud, S., Knowledge acquisition, Knowledge

Yusoff, 2010) conversion, Knowledge application.

(Kimaiyo et Knowledge acquisition, Knowledge

al., 2015) conversion, knowledge application,

Knowledge protection

Knowledge infrastructure capability : Technology, Organizational culture,

(Mills \& Organizational structure; Knowledge

Smith, 2011) process capability : Knowledge acquisition, Knowledge conversion, Knowledge application, Knowledge protection. Knowledge Creation, Knowledge acquisition, Knowledge Collation,

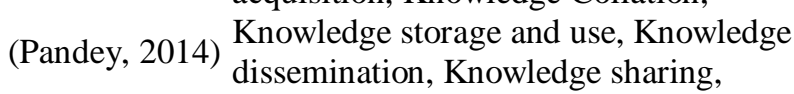
Knowledge reuse and synthesis, Knowledge capitalization, Knowledge audit.

\section{SMEs Performance}

According to(Moeheriono,2014), definition ofperformance is a description of the level of achievement of the implementation of an activity program or policy in realizing the goals, objectives, vision and mission of the organization as outlined in the strategic planning of an organization. On the other hand, organizational performance refers to ability of an organisation to achieve certain objectives and goals such as good financial results, high organisation profit, and produce high quality products by using effective strategies adopted(Wahab, Rahmat, Yusof, \& Mohamed, 2016).Performance is the organization's ability to manage finance and non-finance to achieve the vision, mission and mission of the organization.

In this study, performance measures used using the balanced scorecard approach. According to (Kaplan \& Norton, 1996)the balanced scorecard complements traditional financial measures with criteria that measure performance from three additional perspectives, namely customers, internal business processes, and learning and growth. This means that performance is not only measured from financial aspects, but non-financial aspects are measured to assess the performance of an organization.

In preparing the Balance Score Card, there are four perspectives that are used as the basis for the frame of mind (Kaplan \& Norton, 1996), namely: Financial Perspective, Customer Perspective, Business Process Perspective and Growth and Learning Perspective. 


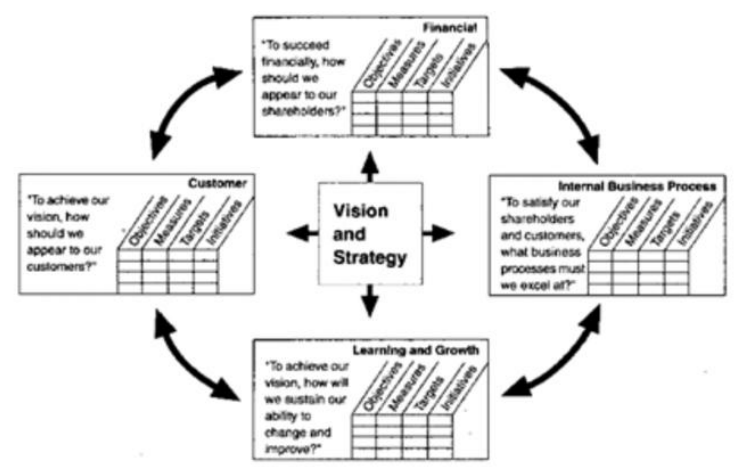

Fig1General Framework of The Balanced Scorecard (Kaplan \& Norton, 1996)

Supported by many of the most successful organizations in the world, the Balanced Scorecard (BSC) was developed by (Kaplan dan Norton, 1992; Craig \& Moores, 2010)to link measurement of financial and non-financial indicators with company strategies.According to(Rufaidah, 2014), Balance Score Cardis a strategic planning and management system that is very often used in a business and industry, government, and non-profit organizations in the world. This tool helps to equate business activities with the vision and strategy of the organization, improve internal and external communication, and monitor organizational performance that is tailored to the strategic objectives of the organization. This method is a measurement framework that combines strategic non-financial performance measurement into traditional financial matrix, in an effort to provide a more balanced picture of organizational performance.

From past research, it can be concluded that SMEs performance indicators are: 1) financial perspective; 2) internal perspective of business processes; 3) customer and stakeholder perspectives; and 4) learning and growth perspective.

\section{Conceptual Framework}

In line with an extensive review of previous research, the conceptual framework as shown in Figure 2 was built to show the relationship between knowledge management capabilities and organizational performance. We argue that the four dimensions underlying the knowledge management process 1) Knowledge creation / acquisition; 2) knowledge storage; 3) knowledge transfer / sharing; and 4) knowledge utilization) has a positive relationship to organizational performance.
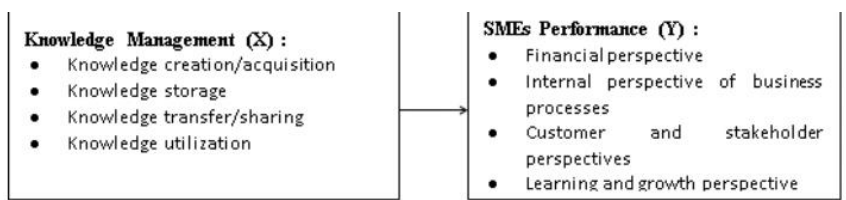

Fig2:Conceptual Framework

$\mathrm{X} 1=$ Knowledge Management

$\mathrm{Y}=$ SMEs Performance

$=$ The line describes the influence

From past research, it can be concluded that knowledge management indicators are: 1) Knowledge creation/acquisition; 2) knowledge storage; 3) knowledge transfer/sharing; dan 4) knowledge utilization. In the above explanation, the hypothesis in this study are:

$\mathrm{H}$ : Knowledge management is positively and significantly related to the performance of SMEs
H1: Knowledge creation / acquisition is positively and significantly related to the performance of SMEs

$\mathrm{H} 2$ : Knowledge storage is positively and significantly related to the performance of SMEs

H3: Knowledge transfer / sharing is positively and significantly related to the performance of SMEs

$\mathrm{H} 4$ : Knowledge utilization is positively and significantly related to the performance of SMEs

\section{Methodology}

\section{A. Research Objects}

Objects in this study consist of 2 variables: Knowledge Management and SMEs Performance. Knowledge Management is Business Incubator Services which are independent variables (indeventent variables), and SMEs Performance which is the dependent variable (devendent variable). In order to obtain a simplification of data analysis in the study, Knowledge Management (X) and SMEs Performance are given a symbol (Y). As for the respondents or objects in this study are SMEs in Bandung City.

\section{B. Research Method}

Based on the type of research, which is quantitative descriptive carried out through data collection in the field, the research method used is explanatory survey method with the aim to explain the relationship between the variables studied by testing the hypothesis through statistical data processing and testing.According to (Silalahi, 2017), explanatory research is a research whose main purpose is to explain the reason for the occurrence of the event and to form, deepen, develop, or test the theory.

\section{Populationand Sample Withdrawal Technique}

The research population was obtained from the data of the number of SMEs in Bandung City as many as 12,270. Then the sampling in this study was taken randomly. Researchers use this technique because the sample is representative or represents the population and is proportional to the simple process, does not involve population parameters that are not known, and is adjusted to the state of the object of the research in the reception of sample distribution. To determine the minimally representative sample size for testing the hypothesis, determine the sample of the existing population, using the Slovin formula, using a formula like the following

$$
\begin{aligned}
& n=\frac{N}{1+N e^{2}} \\
& \text { As: } \\
& n=\text { Overall sample size } \\
& \mathrm{N}=\text { Population size } \\
& \mathrm{e}=\text { level of error in selecting tolerated sample members } \\
& \text { (the error rate taken in this sampling is } 10 \% \text { ) }
\end{aligned}
$$

By using this formula, the following samples are obtained: $n=\frac{N}{1+N e^{2}}$

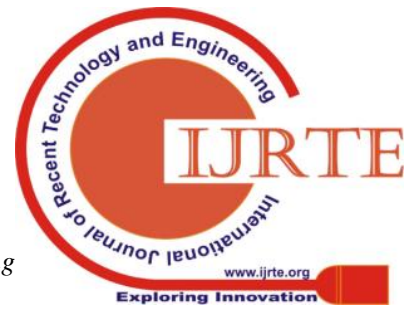




\section{The Impact of Knowledge Management on SMEs Performance in the city of Bandung}

$$
\begin{aligned}
& n=\frac{12.270}{1+12.270(10,1)^{2}} \\
& =99,20 \approx 99
\end{aligned}
$$

Thus the author in this study uses a sample of 99 samples that have been rounded.

\section{Data Analysis Technique}

Based on these guidelines, the authors will make observations to obtain research data in accordance with the research objectives, namely to describe and analyze the Knowledge and Performance Management of UMKM in the City of Bandung.

$\mathrm{H}_{0}: \beta=0$ : There is no effect of knowledge management on the performance of SMEs in the city of Bandung.

$\mathrm{H}_{0}: \beta=0$ : There is no effect of knowledge creation / acquisition on the performance of SMEs in the city of Bandung.

$\mathrm{H}_{0}: \beta=0$ : There is no effect of knowledge storage on the performance of SMEs in the city of Bandung.

$\mathrm{H}_{0}: \beta=0$ : There is no effect of knowledge transfer / sharing on the performance of SMEs in the city of Bandung.

$\mathrm{H}_{0}: \beta=0$ : There is no effect of knowledge utilization on the performance of SMEs in the city of Bandung.

$\mathrm{H}_{1}: \beta \neq 0$ : There is an influence of knowledge management on the performance of SMEs in the city of Bandung.

$\mathrm{H}_{1}: \beta \neq 0$ : There is an influence of knowledge creation / acquisition on the performance of SMEs in the city of Bandung.

$\mathrm{H}_{1}: \beta \neq 0$ : There is an influence of knowledge storage on the performance of SMEs in the city of Bandung.

$\mathrm{H}_{1}: \beta \neq 0$ : There is an influence of knowledge transfer / sharing on the performance of SMEs in the city of Bandung.

$\mathrm{H}_{1}: \beta \neq 0$ : There is an influence of knowledge utilization on the performance of SMEs in the city of Bandung.

The significance test of the correlation coefficient is done by $t$ test ( $t$ test). The results of the correlation significance test determine whether the researcher must make a decision to reject the null hypothesis $\left(\mathrm{H}_{0}\right)$ and accept the alternative hypothesis $\left(\mathrm{H}_{1}\right)$ or accept $\mathrm{H}_{0}$ and reject $\mathrm{H}_{1}$ after comparing the results of the $t$ test (empirical) and t-table (theoretical): (a) If $\mathrm{p}<0.05$ or $\mathrm{t}$ count $<\mathrm{t}$ table then $\mathrm{H}_{0}$ is not rejected; and (b) If $\mathrm{p}<0.05$ or $\mathrm{t}$ count $>\mathrm{t}$ table then $\mathrm{H}_{0}$ is rejected.

\section{RESUlts AND FINDINGS}

The next problem to be answered in this study is "How is the influence of knowledge management on theSMEs performance in the city of Bandung?" Based on these problems, the analysis of the influence of knowledge management on the SMEsperformance presented below is based on the results of simple regression analysis. Simple regression is used to determine the effect of knowledge management variables partially on theSMEs performance.

TABLE3 : REGRESSION COEFFICIENT, T $_{\text {COUNT AND PROBABILITY VALUE }}$

\begin{tabular}{lllllll}
\hline \multirow{2}{*}{ Model } & \multicolumn{3}{l}{$\begin{array}{l}\text { Unstandardized } \\
\text { Coefficients }\end{array}$} & $\begin{array}{l}\text { Standardize } \\
\mathrm{d} \\
\text { Coefficients }\end{array}$ & $\mathrm{t}$ & Sig. \\
& $\mathrm{B}$ & Std. Error Beta & & \\
\hline 1 & $\begin{array}{l}\text { (Constant) } \\
\text { Knowledge }\end{array}$ & 44.196 & 5.958 & & 7.418 & .000 \\
& $\begin{array}{l}\text { Management } \\
\text { (Constant) }\end{array}$ & 1.322 & .085 & .846 & 15.635 & .000 \\
2 & 54.430 & 7.078 & & 7.690 & .000 \\
$\begin{array}{l}\text { Knowledge } \\
\text { creation/acquisitionn }\end{array}$ & 4.991 & .427 & .765 & 11.696 & .000
\end{tabular}

\begin{tabular}{lllllll} 
(Constant) & 65.552 & 5.817 & & 11.269 & .000 \\
4 & $\begin{array}{l}\text { Knowledge } \\
\text { strorage } \\
\text { (Constant) }\end{array}$ & 4.466 & .361 & .782 & 12.372 & .000 \\
& $\begin{array}{l}\text { Knowledge } \\
\text { transfer/sharing } \\
\text { (Constant) }\end{array}$ & 4.794 & .393 & .778 & 12.205 & .000 \\
& 48.176 & 6.483 & & 7.431 & .000 \\
\hline
\end{tabular}

a. Dependent Variable: SMEs performance

Based on these results, research has answered the questions contained in the formulation of the problem, namely how the influence of knowledge management on the performance of SMEs in the city of Bandung. In the table above it can be concluded that 1) Against the positive and significant influence between knowledge management and SME performance where the value of $\mathrm{p}<0.05=0.000<0.05$ so that $\mathrm{H}_{0}$ is rejected, which means that independent knowledge management variables partially have a positive and significant effect on SME performance variables; 2) Regarding the positive and significant influence between knowledge creation / acquisition and SME performance where the $\mathrm{p}$ value $<0.05=0.000<0.05$ so that $\mathrm{H}_{0}$ is rejected, which means that the independent variable knowledge creation / acquisition partially has a positive and significant effect on the SME performance variable; 3) On the positive and significant influence between knowledge storage and SME performance where the value of $\mathrm{p}<0.05=0,000<0.05$ so that $\mathrm{H}_{0}$ is rejected, which means that the independent knowledge storage variable partially has a positive and significant effect on the SME performance variable; 4) Against the positive and significant influence between knowledge transfer / sharing and SME performance where the value of $\mathrm{p}<0.05=0,000<0.05$ so that $\mathrm{H}_{0}$ is rejected, which means the independent variable knowledge transfer / sharing partially has a positive and significant effect on the SME performance variable; 5) Against the positive and significant influence between knowledge utilization and SME performance where the value of $\mathrm{p}<0.05=0,000<0.05$ so that $\mathrm{H}_{0}$ is rejected, which means that the independent variable utilization of utilization partially has a positive and significant effect on the SME performance variable. This research has proven that knowledge management (knowledge acquisition, knowledge storage, knowledge transfer / sharing, knowledge utilization) has proven to have a positive and significant influence on the performance of SMEs (financial perspective; internal perspective of business processes; customer and stakeholder perspectives; and learning and growth perspective), so that the more effective the implementation of knowledge management, the higher the performance of SMEs obtained, and vice versa.

\section{Conclusion}

Based on the results of hypothesis testing shows that knowledge management has a positive and significant influence on the performance of SMEs, meaning that if knowledge management is high then the performance of SMEs will be high and vice versa if knowledge management is low then the performance of SMEs will be low. 
This result is in line with previous research(Gharakhani \& Mousakhani, 2012)which states that knowledge management has a positive and significant effect on the performance of SMEs.Another research ( $\mathrm{Ha}$ et al., 2016)states that knowledge management has a positive and significant influence on the performance of SMEs. Knowledge of acquisition, knowledge storage, knowledge transfer / sharing and knowledge utilization is proven to have a positive and significant effect on the performance of SMEs.

Based on the conclusions from the discussion of simple regression results, the authors convey some suggestions to the company and to other researchers to examine the knowledge management variables and the performance of SMEs described as follows: 1) To improve the performance of SMEs, companies must pay attention to and improve the quality of knowledge management, because based on this study knowledge management variables have a positive and significant influence on the performance of SMEs; and 2) In this study there are other independent variables that might influence the performance of SMEs that were not included in this study, so that for the next researcher other variables could be examined.

Theoretically the usefulness of this research is as a means to add references and study material in the repertoire of knowledge, especially in the field of management. Practically, the usefulness of this research is (1) as information material for SMEs regarding knowledge management and consideration for improving performance; (2) as input material for preliminary studies for further researchers to understand the effect of knowledge management on performance.

However, this study has several limitations: (1) the number of respondents is only obtained in one city, namely SMEs in the city of Bandung, which of course the possibility of the results will be different from other cities; (2) The variables studied only reveal the influence of knowledge management on performance, while many other factors influence performance that have not been revealed in this study. Of course this will be an input for further researchers to uncover other factors that affect performance.

\section{ACKNOWLEDGEMENT}

This research was funded and supported by Indonesia Endowment Fund for Education (LPDP). In this great chance, researchers want to say thanks to LPDP for all the help.

\section{REFERENCES}

1. Abubakar, A. M., Elrehail, H., Alatailat, M. A., \& Elçi, A. (2017) Knowledge management, decision-making style and organizational performance. Journal of Innovation \& Knowledge, 1-15. https://doi.org/10.1016/j.jik.2017.07.003

2. Adman; Suwatno; Tjutju Yuniarsih. (2017). Development of Managerial Competence through Knowledge Management. In 1st Annual Applied Science and Engineering Conference (Vol. 9, pp. 533-539). IOP

Publishing. https://doi.org/10.1088/1742-6596/755/1/011001

3. Alaarj, S., Abidin-Mohamed, Z., \& Binti Ahmad Bustamam, Salwa, U. (2016). Mediating Role of Trust on the Effects of Knowledge Management Capabilities on Organizational Performance. Procedia Social and Behavioral Sciences, 235(October), 729-738. https://doi.org/10.1016/j.sbspro.2016.11.074

4. Anggadwita, G., \& Mustafid, Q. Y. (2014). Identification of Factors Influencing the Performance of Small Medium Enterprises (SMEs).

Procedia - Social and Behavioral Sciences, 115, 415-423. https://doi.org/10.1016/j.sbspro.2014.02.448

5. Armstrong, M., \& Taylor, S. (2014). Handbook of human resource management practice. John Wiley \& Sons (13th ed.). British: Kogan Page. https://doi.org/10.1177/030913258901300105

6. Badan Pusat Statistik Kota Bandung. (2017). Kota Bandung Dalam Angka 2017

7. Bolisani, E., \& Bratianu, C. (2017). Knowledge strategy planning: an integrated approach to manage uncertainty, turbulence, and dynamics. Journal of Knowledge Management, 21(2), 233-253. https://doi.org/10.1108/JKM-02-2016-0071

8. Budihardjo, A. (2017). Knowledge Management : Efektif Berinovasi Meraih Sukses. Jakarta: Prasetiya Mulya Publishing.

9. Chin, T. A., Hamid, A. B. A., Rasli, A., \& Baharun, R. (2012) Adoption of Supply Chain Management in SMEs. Procedia - Social and Behavioral Sciences, 65(ICIBSoS), 614-619. https://doi.org/10.1016/j.sbspro.2012.11.173

10. Chin, T. A., Hamid, A. B. A., Rasli, A., \& Tat, H. H. (2014). A Literature Analysis on the Relationship between External Integration, Environmental Uncertainty and Firm Performance in Malaysian SMEs. Procedia - Social and Behavioral Sciences, 130, 75-84 https://doi.org/10.1016/j.sbspro.2014.04.010

11. Cho, T., \& Korte, R. (2014). Managing knowledge performance: Testing the components of a knowledge management system on organizational performance. Asia Pacific Education Review, 15(2), 313-327. https://doi.org/10.1007/s12564-014-9333-x

12. Craig, J., \& Moores, K. (2010). Strategically aligning family and business systems using the Balanced Scorecard. Journal of Family $\begin{array}{lll}\text { Business } & \text { Strategy, } & \text { 78-87. }\end{array}$ https://doi.org/10.1016/j.jfbs.2010.04.003

13. Daud, S., Yusoff, W. F. W. (2010). Knowledge management and firm performance in SMEs: The role of social capital as a mediating variable. Academy of Management Journal, 15(2), 135-155.

14. Gharakhani, D., \& Mousakhani, M. (2012). Knowledge management capabilities and SMEs' organizational performance. Journal of Chinese Entrepreneurship, 4(1), https://doi.org/10.1108/17561391211200920

15. Ha, S.-T., Lo, M.-C., \& Wang, Y.-C. (2016). Relationship between Knowledge Management and Organizational Performance: A Test on SMEs in Malaysia. Procedia - Social and Behavioral Sciences, 224(August 2015), https://doi.org/10.1016/j.sbspro.2016.05.438

16. Iqbal, A., Agha, K., Ali, A., \& Qureshi, M. I. (2016). Financial Policy and Capital Structure Choice in Pakistan SMEs: Empirical Evidence from Company Panel Data Athar. Abasyn Journal of Social Sciences, $358-375$.

17. Islam, M. A., Agarwal, N. K., \& Ikeda, M. (2017). Effect of knowledge management on service innovation in academic libraries. IFLA Journal, 43(3), 266-281. https://doi.org/10.1177/0340035217710538

18. Kaplan, R. S., \& Norton, D. P. (1996). Robert S. Kaplan, David P. Norton-The Balanced Scorecard_ Translating Strategy into Action -Harvard Business Press (1996).pdf. Harvard Business Press.

19. Kimaiyo, I. K., Kapkiyai, C., \& Sang, J. C. (2015). Effect of Knowledge Management on Firm Performance in Commercial Banks in Nakuru, Eldoret And Kisumu. European Journal of Business and ManagementOnline), 7(3), 2222-2839.

20. Lee, W.-T., Hung, S.-Y., \& Chau, P. Y. K. (2011). Influence of Knowledge Management Infrastructure on Innovative Business Processes and Market-Interrelationship Performance. Journal of Global Information Management, 19(2), 67-89. https://doi.org/10.4018/jgim.2011040104

21. Liu, S., \& Deng, Z. (2015). Article information: Management Decision, $53(1)$, $124-138$ https://doi.org/http://dx.doi.org/10.1108/MRR-09-2015-0216

22. Mahdi, O. R., Nassar, I. A., \& Almsafir, M. K. (2018). Knowledge management processes and sustainable competitive advantage: An empirical examination in private universities. Journal of Business Research, (May 2017). https://doi.org/10.1016/j.jbusres.2018.02.013

23. Mills, A. M., \& Smith, T. A. (2011). Knowledge management and organizational performance: A decomposed view. Journal of Knowledge Management, 15(1), 156-171. https://doi.org/10.1108/13673271111108756

24. Moeheriono. (2014). Pengukuran Kinerja Berbasis Kompetensi. Jakarta: Rajawali Pers.

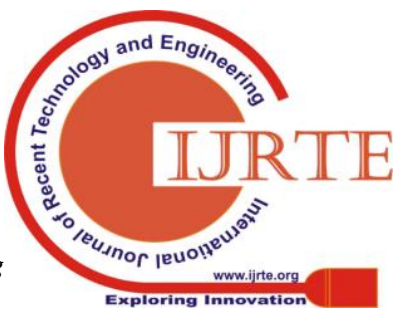


25. Pandey, K. N. (2014). Knowledge Management Processes: A Case Study of NTPC and POWERGRID. Global Business Review, 15(1), 151-174. https://doi.org/10.1177/0972150913515592

26. Rufaidah, P. (2014). Manajemen Strategik. Bandung: Humaniora.

27. Sarwono, H. A. (2015). Profil Bisnis Usaha Mikro, Kecil Dan Menengah (UMKM). Bank Indonesia Dan LPPI, 5-57.

28. Shujahat, M., Ali, B., Nawaz, F., Durst, S., \& Kianto, A. (2018). Translating the impact of knowledge management into knowledge-based innovation: The neglected and mediating role of knowledge-worker satisfaction. Human Factors and Ergonomics In Manufacturing, 28(4), 200-212. https://doi.org/10.1002/hfm.20735

29. Si Xue, C. T. (2017). A Literature Review on Knowledge Management in Organizations. Research in Business and Management, 4(1), 30. https://doi.org/10.5296/rbm.v4i1.10786

30. Silalahi, U. (2017). Metode Penelitian Sosial Kuantitatif. Bandung: PT Refika Aditama.

31. Torabi, F., \& El-Den, J. (2017). The impact of Knowledge Management on Organizational Productivity: A Case Study on Koosar Bank of Iran. Procedia Computer Science, 124, 300-310. https://doi.org/10.1016/j.procs.2017.12.159

32. Torabi, M. H. R., Kyani, A., \& Falakinia, H. (2016). An Investigation of the Impact of Knowledge Management on Human Resource Performance in Management of Keshavarzi Bank Branches in Tehran. Procedia - Social and Behavioral Sciences, 230(May), 471-481. https://doi.org/10.1016/j.sbspro.2016.09.059

33. Tubigi, M., Alshawi, S. N., \& Alalwany, H. (2013). Impact of Knowledge Management Processes on Organisational Performance; a Preliminary Study, 2013, 1-16.

34. Wahab, S., Rahmat, A., Yusof, M. S., \& Mohamed, B. (2016) Organization Performance and Leadership Style: Issues in Education Service. Procedia - Social and Behavioral Sciences, 224(August 2015), 593-598. https://doi.org/10.1016/j.sbspro.2016.05.447

35. Wang, Y., Bhanugopan, R., \& Lockhart, P. (2015). Examining the quantitative determinants of organizational performance: Evidence from China. Measuring Business Excellence, 19(2), 23-41. https://doi.org/10.1108/MBE-05-2014-0014

\section{AUTHORS PROFILE}

ArdiApriliadi, Indonesia Endowment Fund for Education (LPDP), Full Time Students, Master of Management ScienceProgram, UniversitasPadjadjaran. ardi.apriliadi@gmail.com

Adman, Lecturer atFaculty of Economicsand Business Education, Universitas Pendidikan Indonesia. adman@upi.edu. 